(A Peer-Reviewed, Open Access Journal)

\title{
The Effects of Telecommunication Service Quality Dimensions on Customer Satisfaction in Kathmandu Valley
}

\author{
Gunja Kumari Sah*
}

Shiva Prasad Pokharel ${ }^{* *}$

DOI: https://doi.org/10.3126/jnbs.v14i1.41498

Received on 12 June 2021

Accepted on 10 November 2021

\begin{abstract}
Telecommunications have become a vital tool for the success of any business. The 21stcentury telecommunication business has been described by hi-tech competition, which has brought attention to customer satisfaction. The study aimed to identify major influential dimensions that affect customer satisfaction. It was accompanied by a descriptive and causal research design and used a structured questionnaire as a survey instrument of the service quality (SERVQUAL) model. The population of this research covered all customers of the Telecommunication industry located at Kathmandu valley, and the sample considered 400 customers through convenience sampling techniques. The survey questionnaire was set in three sections with 38 questions of various types to collect data. The result showed a noteworthy strong positive relationship between service quality dimensions and customer satisfaction. It also revealed security was the major influential dimension of customer satisfaction, followed by tangibles, assurance, and empathy. The finding of the study helps all telecommunication industries to enhance service quality and develop a strategy to increase customer satisfaction and value. Hence, it infers that security, tangibles, assurance, and empathy increase the customer's satisfaction in telecommunications services. Overall service quality dimensions are commonly considered as crucial features of customer satisfaction.
\end{abstract}

Keywords: Customer satisfaction, service quality, SERVQUAL model, telecommunication

\section{INTRODUCTION}

Information technology (IT) acts as a significant tool in the advancement of our life. The telecommunication industry is rapidly growing through globalization and technological innovation. In modern trade and business, the mobile telecommunications industry has been described by high technological advancement, which has attracted the attention to customer

\footnotetext{
${ }^{*}$ Ms. Sah is an Assistant Professor at Patan Multiple Campus, Tribhuvan University.

Email: gunja.sah@pmc.tu.edu.np

** Mr. Pokharel is an Associate Professor at Patan Multiple Campus, Tribhuvan University. Corresponding Author: Gunja Kumari Sah
} 
satisfaction and has become tremendously essential for the success of the business. Customer Satisfaction is an emotion of happiness or unhappiness resulting from deviating a product's or service's perceived performance with expectations (Kotler, 2011). It generally refers to a decision of customers towards products or services performances (Kotler \& Keller, 2006). So, it is a function of the performance of products and services and customers' expectations (Dahal, 2019). In this globalization age, achieving a higher level of customer satisfaction is a tough task in the service segment. Therefore, many service sectors have initiated to advance their service quality and provide improved services to their customers. Hence, telecom sectors need to keep up their service quality dimensions to maintain sustainability for a longer period. The telecommunication sector needs to concentrate on those service quality dimensions, which resulting customer satisfaction (Dahal, 2019; Shrestha \& Ale, 2020).

Telecommunication services in Nepal began in B.S. 1948 with the foundation of Mohan Akashwani. With the formulation of a five-year plan (1955-1960), Telecommunication Department was founded in B.S.1959. During the third five-year plan (1966-1970), the Telecommunications Department was transformed into the Telecommunications Development Board in 1969 to upgrade and expand telecommunications services. It was formally known as a government corporation recognized by Nepal Telecommunications Corporation (NTC) in 1975, after enacting the Communications Corporation Act 1971. On April 13, 2004, NTC was renamed Nepal Doorsanchar Company Limited after 29 years. The Nepal Doorsanchar Company Limited is a company with a limited liability established under the Companies Act of 1996 (NTA, 2020).

Nepal Doorsanchar Company Ltd., also known as Nepal Telecom, is Nepal's nationalized telecommunications service provider with $91.49 \%$ of the government share (Dahal, 2019; Shrestha \& Ale, 2020). The corporation was a monopoly until 2004, when the Nepal Telecommunications Policy was passed, paving the path to the liberalization of Nepal's telecommunications sector (Gautam, 2016). Nepal's telecom sector has proven to be fiercely competitive. Till now, there have been four telecom operators in Nepal. They are Nepal Telecom, Ncell, STPL, and NSTPL, with a broad range of technologies (NTA, 2020).

Nepal telecom captured a $52.32 \%$ market share, whereas Ncell captured $42.16 \%$ and the remaining 5.51\% STPL and 0.01\% NSTPL of Nepalese GSM (Global System for Mobile communication) market (NTA, 2020). As competition has escalated among the operators, they must learn about customer satisfaction regarding service quality dimensions such as responsiveness, reliability, assurance, tangibles, empathy, and security. In today's hypercompetitive age, achieving and maintaining achievement by satisfying consumers is a vital challenge for every firm and head of the company, particularly in service industries like telecommunication services. The highly competitive market requires extreme satisfaction from the customer. This study plays a significant role for the telecommunication industry to improve service quality and customer satisfaction. Thus, the telecommunication industry needs to identify the major influential dimensions of service quality to increase customer satisfaction and value.

Hence, this research aimed to find the relationship between service quality dimensions and customer satisfaction. It also examined which aspect of service quality impacts customer satisfaction in the telecommunications sector. Depending on the research questions, the objectives of this study were to examine the relationship between service quality dimensions and customer satisfaction and to identify the major influencing dimensions of service quality that affect customer satisfaction. 


\section{LITERATURE REVIEW}

The exploratory research conducted by Zeithaml et al. (1985) offered several insights and propositions of service quality. The research considered ten factors: reliability, responsiveness, competence, access, courtesy, communication, credibility, security, understanding, and tangibles. The study established four key gaps in the service provider's side that affect service quality as perceived by consumers.

Wang and Lo (2002) studied service quality dimensions, customer satisfaction and value, and behavioral intentions in China's phone market. The study was based on the SERVQUAL model. The result showed that network quality was one of the major dimensions of service quality of customer satisfaction, and customer value in China's mobile phone market.

Turel and Serenko (2006) researched the antecedents of customer satisfaction and loyalty with mobile service in Canada. They obtained data from 210 young adult cellular subscribers. They used descriptive and structural equation modeling to analyze data and fit the model. They found high internal consistency and reasonably high convergent validity correlations.

In 2009 Negi (2009) used the modified SERVQUAL model to examine the causal relationship between tangibles, reliability, responsiveness, empathy, assurance, network aspect, and ease to measure customers' perceptions and expectations of mobile telecommunications in Ethiopia. The result indicated that a significant relationship between reliability and overall service quality.

In Greece Santouridis and Trivellas (2010) investigated essential factors that affect customer faithfulness in the mobile telephony segment. The result showed the customer service, pricing policy, and system that have a noteworthy positive influence on customer satisfaction leading to a significant positive influence on customer loyalty.

Arokiasamy and Abdullah (2013) studied the service quality dimensions and customer satisfaction in Malaysia's cell phone service supplier. They also employed the SERVQUAL model to examine the relationship between the service quality dimensions and customer satisfaction, determining that service quality dimensions affected customer satisfaction positively in terms of loyalty and attitudes.

In Nepal, Gautam (2016) researched strategies of NTC and Ncell telecommunication networks. The results showed that NTC and Ncell are the two most potent telecom companies in Nepal. NTC continues to lead in terms of total users; nevertheless, Ncell recently overtook NTC as the biggest provider of GSM mobile lines. In the Nepalese banking sector, Bhatta \& Durgapal (2016) researched bank customers' perception of service quality and satisfaction by the service performance SERPERF model. They obtained data from 300 customers of six banks situated in Kathmandu. According to them, customer satisfaction was statistically predicted by reliability, tangibility, empathy, and responsiveness. Neupane and Devkota (2017) identified the effects of service quality on patient satisfaction in the health sector. According to the findings, private hospitals in Nepal provide a high degree of service quality in the eyes of patients. They also discovered a high level of patient satisfaction in Nepal's private hospitals.

In the telecommunication sector, Dahal (2019) studied Nepal Telecoms' global system for mobile network customer satisfaction. Data were obtained from 562 customers who were randomly chosen using judgmental sampling techniques. Five dimensions such as innovation, corporate social responsibility, network, brand image, price, services and one moderator (occupation), were found to be antecedents of GSM network customer satisfaction. Similarly, Shrestha and Ale (2020) investigated the impact of service quality factors on the perceived performance of Nepal Telecom phone users in Nepal's Kathmandu valley. The SERVQUAL model's five service quality dimensions were the focus of the research. A 
probabilistic sampling strategy was used to acquire data from 200 respondents. All five measures of service quality had a favorable and significant effect on customer satisfaction. Customers must consider the telecommunications service quality as a reference when selecting telecommunication service providers of good quality and service (Yulisetiarini \& Prahasta, 2019).

A significant number of studies have been carried out to find out the service quality of various sectors. Although various studies on service quality have been reported (Dahal, 2019; Rahhal, 2015; Shrestha 2018; Yousapronpaiboon, 2014), there has been limited study on service quality and customer satisfaction throughout the entire telecommunications sector. In today's highly competitive industry, it's critical to keep consumer satisfaction at a high level. Although customer satisfaction is not a complete solution for business problems, it is a helpful tool for determining how well a firm performs and maintains service quality. In contrast, this study focused on the service quality model to understand the level of service quality dimensions and its impact on customer satisfaction of the telecommunication industry in Nepal.

\section{Theoretical Framework}

The framework suggests service quality dimensions are associated with customer satisfaction. Based on the literature, customer satisfaction depends on service quality dimensions of the SERVQUAL model. This framework consists of responsiveness, reliability, assurance, tangibles, empathy, and security as independent variables, customer satisfaction as a dependent, and gender, age, occupation, and education as moderating variables.

\section{Figure 1}

Theoretical Framework (Parasuraman et al., 1985 \& Zeithaml et al. (1985)

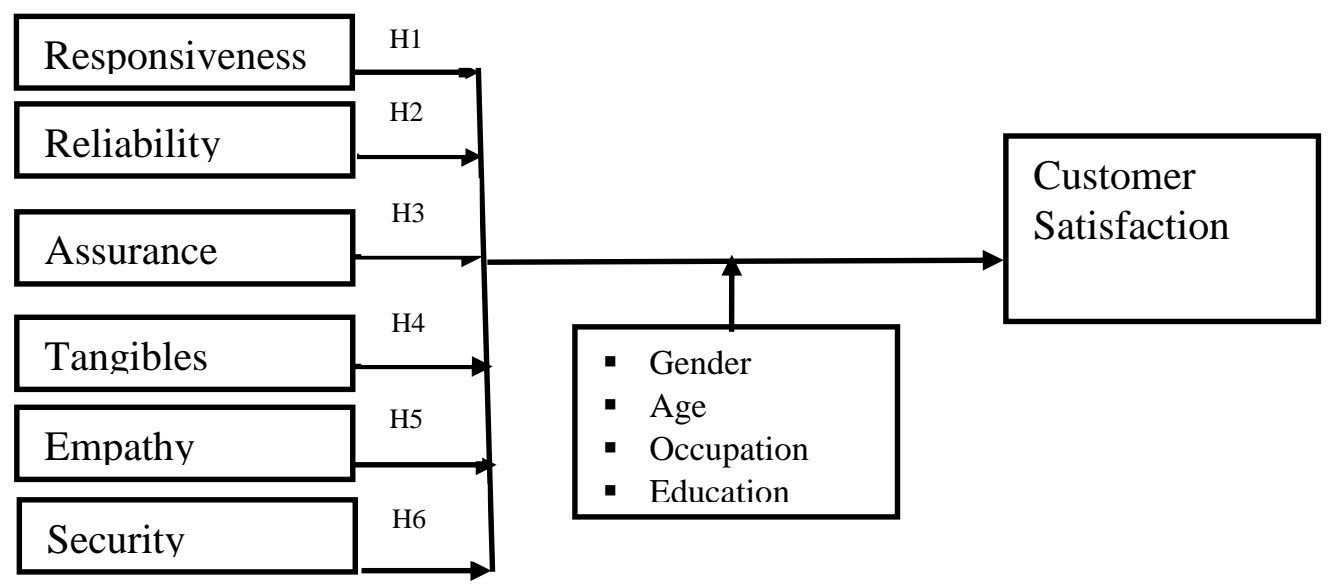

\section{Research Hypothesis}

The above framework would lead to the following hypotheses:

$\mathrm{H} 1$ : There is a significant relationship between responsiveness and customer satisfaction

$\mathrm{H} 2$ : There is a significant relationship between reliability and customer satisfaction

H3: There is a significant relationship between assurance and customer satisfaction

H4: There is a significant relationship between tangibles and customer satisfaction.

H5: There is a significant relationship between empathy and customer satisfaction.

H6: There is a significant relationship between security and customer satisfaction. 
The moderating effect of customer's gender, age, occupation, and education was hypothesized as follows:

Ha: Customer satisfaction differs as per customer's gender

$\mathrm{Hb}$ : Customer satisfaction differs as per the customer's age

Hc: Customer satisfaction differs as per occupation

Hd: Customer satisfaction differs as per education

\section{METHODOLOGY}

The study used a descriptive and causal research design, and it was conducted among 600 respondents in the Kathmandu valley by a primary survey through a structured questionnaire. The targeted population of the study consisted of all the consumers within the Kathmandu valley who used telecommunication services. The study employed a convenience sampling technique. Targeted respondents of the study were: students, servicepersons, businesspeople, and unemployed, etc. According to Cooper and Schndler (2014), the sample size in the research should not be less than 385 respondents. The sample size was also by the guidelines of selecting sample size (Krejcie \& Morgan, 1970). The structured questionnaire for the survey involved 38 questions and was prepared into three sections. The first section comprised demographic information, the second section demanded telecommunication service-related, and the final section asked for the various service quality dimensions and overall customer satisfaction-related information. All 28 survey items of the study variables were measured with a 5-point Likert-type scale with $1=$ strongly disagree to $5=$ strongly agree.

The questionnaires were distributed in two ways: online survey and field survey. During the 60 days of January-February 2019, 300 people were contacted via an online survey, and 198 people responded. On the other side, a field survey for 300 questionnaires was also done, with 250 being gathered at the same period. From gathered questionnaires, 48 questionnaires were discarded, and 400 questionnaires were valid and entered into Statistical Package for Social Science (SPSS) version 20. Descriptive and inferential techniques analyzed data. The frequency analysis was used to describe the demographic information of telecommunication users. Reliability (Cronbach's Alpha) analysis was employed to examine the internal consistency of the structured questionnaires used in the study. Descriptive statistics was done to summarize the constructs. Correlation analysis was used to check the association between constructs. Multiple regression analysis was used to access the effect of independent variables on the dependent variable as well as test the hypotheses assumed. Independent sample t-test and analysis of variance test used to analyze the moderating effect on the dependent variable.

\section{RESULTS AND DISCUSSION}

The results of various tests are discussed with each of the relevant research objectives. According to demographic status, most of the respondents were males with 55.3 percent and females with 44.7 percent. Regarding age group, the respondents were 42.5 percent of 15-24, 40.2 percent of 25-34, 12 percent of 35-45, and 5.3 percent above 45 . According to education, respondents were not formally educated 5 percent; secondary educated 11.8 percent, bachelor's degree holders 52 percent, and master degree holder 31.2 percent. In terms of occupation, 50.8 percent were service holders, 15 percent were businessperson, 27.5 percent were students, and 6.7 percent were of the unemployed group. Regarding using the network, 67.7 percent of respondents chose the NTC network as their 
first choice, 28.5 percent used Ncell, 3.3 percent used STPL, and only 0.5 percent used others. They used telecommunication services for personal use 42.3 percent, for business use 10.5 percent, and 47.2 percent took services for both personal and professional purposes. According to the duration of using telecommunication service, 7.3 percent used it less than two years, 30.3 percent used it two to five years, 40.7 percent used it from the last 10 years and 21.7 percent used it more than 10 years. In terms of the tariff of telecommunication service, 72.3 percent used prepaid tariffs, and 27.8 percent used postpaid tariffs.

One of the most important criteria for evaluating research instruments is reliability, which refers to the internal consistency of the variables (Chu \& Murrmann, 2006). As a result, Cronbach's alpha (a) analysis was utilized to assess the internal consistency of the structured questionnaires. Nunnally (1978) suggested that a reliability level of 0.70 is accepted. According to Hair, et al. (1998), Cronbach's Alpha should be more than 0.7, and it is considered as a suitable value for measuring internal consistency.

\section{Table 1}

Cronbach's Alpha of Various Constructs for Internal Consistency

\begin{tabular}{lc}
\hline Variables & Cronbach's Alpha \\
\hline Responsiveness & 0.822 \\
Reliability & 0.823 \\
Assurance & 0.834 \\
Tangibility & 0.830 \\
Empathy & 0.820 \\
Security & 0.826 \\
Customer Satisfaction & 0.814 \\
\hline
\end{tabular}

Source: Survey, 2019

Table 1 shows alpha values ranging from 0.814 to 0.834 , indicating an acceptable level of reliability. It was used to determine the items' internal consistency (Dahal, 2019; Shrestha, 2018). Bhatta and Durgapal (2016) also found Cronbach's alpha values were above 0.70. Since, Cronbach's alpha value is more than 0.7 , which states that all the constructs are acceptable.

Descriptive statistics were employed to summarize the data. The mean and standard deviation were used to describe the data (Marshall \& Jonker, 2010; Thompson, 2009). The mean value indicates the average value, and the standard deviation measures the distribution of the scores around the mean. The mean value greater than three and standard deviation value less than 1 was presumed that respondents gave positive responses to Likert statements. The descriptive data are shown in Table 2.

Table 2

The Descriptive Statistics of Different Construct to Analyze Customer Satisfaction

\begin{tabular}{lcc}
\hline Variables & Mean & Std. Deviation \\
\hline Responsiveness & 3.381 & 0.827 \\
Reliability & 3.376 & 0.827 \\
Assurance & 3.506 & 0.757 \\
Tangibles & 3.442 & 0.775 \\
Empathy & 3.380 & 0.798 \\
Security & 3.503 & 0.802 \\
Customer Satisfaction & 3.530 & 0.781 \\
\hline
\end{tabular}

Source: Survey, 2019 
Table 2 explains that the mean scores of the composite variables in this study were between 3.376 and 3.530, which means almost all respondents agree with the service quality dimensions and customer satisfaction. It indicates a standard deviation value between 0.757 of 0.827 . The mean value must be greater than three, and the standard deviation value must be less than one. In table 2, all the mean value of the constructs was greater than three with a standard deviation less than one (Thompson 2009). So, the analysis can be generalized. Shrestha and Ale (2020) also reported that the mean score of tangibles was equal to 3.169 and assurance was equal to 3.207, which indicates that customers were satisfied and agreed on the tangibles and assurance with the service provided by Nepal Telecom.

Correlation analysis is used to test the relationship between variables. It depicts the power and direction of the relationship. The Pearson's correlation coefficients were used to identify the strength of linear relationships among independent and dependent constructs. The relationship may be weak, moderate, strong, or very strong, and it may be positive or negative. Correlation analysis is shown in Table 3. The correlation coefficient value ranges between +1 and -1 in terms of the strength of the relationship. The correlation coefficients range from -1 to +1 , with -1 denoting perfect negative and +1 positive correlation coefficients, respectively; 0 denotes no correlation (zero relationships). Furthermore, correlation coefficients less than 0.40 (whether negative or positive) are considered low, moderate between 0.40 and 0.60 , and strong above 0.60 (Isaac, 2018).

\section{Table 3}

\section{Correlation Matrix}

\begin{tabular}{llc}
\hline Service Quality Dimensions & & Customer Satisfaction \\
\hline Responsiveness & Pearson Correlation & $.789^{* *}$ \\
Reliability & Sig. & 0.000 \\
& Pearson Correlation & $.775^{* *}$ \\
Assurance & Sig. & 0.000 \\
& Pearson Correlation & $.798^{* *}$ \\
Tangibles & Sig. & 0.000 \\
& Pearson Correlation & $.817^{* *}$ \\
Empathy & Sig. & 0.000 \\
& Pearson Correlation & $.810^{* *}$ \\
Security & Sig. & 0.000 \\
& Pearson Correlation & $.827^{* *}$ \\
\hline
\end{tabular}

Source: Survey, 2019

Above table 3 shows all the service quality dimensions have a significant positive relationship with customer satisfaction. There is a positive and strong relationship between security and customer satisfaction, whose values are $\mathrm{r}=0.827, \mathrm{p}<0.01$, followed by tangibles and customer satisfaction values of $\mathrm{r}=817, \mathrm{p}<0.01$. Neupane and Devkota revealed that each factor of service quality was positively correlated and significant at the 0.01 level (Neupane $\&$ Devkota, 2017). Bhatta \& Durgapal also found service quality dimensions were strongly correlated with bank customer satisfaction (Bhatta \& Durgapal, 2016).

The regression assumptions were tested based on the findings of normality, linearity, multicollinearity, and error independence before running the regression analysis. There is no collinearity concern if the VIFs value is between 1 and 5 (Rawlings et al., 1998; Ron, 2002). The VIF value ranged from 0.188 to 4.747 , indicating that there was no multicollinearity. The effect of the cause variable on the outcome variable was examined using regression analysis. It is shown in Table 4. 


\section{Table 4}

Regression Analysis

\begin{tabular}{|c|c|c|c|c|c|c|c|}
\hline \multirow[b]{2}{*}{ Model } & \multicolumn{2}{|c|}{$\begin{array}{c}\text { Unstandardized } \\
\text { Coefficients }\end{array}$} & \multirow[b]{2}{*}{$\mathrm{t}$} & \multirow{2}{*}{$\begin{array}{c}\mathrm{p}- \\
\text { value }\end{array}$} & \multicolumn{2}{|c|}{$\begin{array}{c}\text { Collinearity } \\
\text { Statistics }\end{array}$} & \multirow{2}{*}{$\begin{array}{r}\text { Remarks on } \\
\text { Hypothesis } \\
\end{array}$} \\
\hline & $\mathrm{B}$ & Std. Error & & & Tolerance & VIF & \\
\hline (Constant) & 0.162 & 0.089 & 1.831 & 0.068 & & & \\
\hline Responsiveness & 0.073 & 0.049 & 1.486 & 0.138 & 0.188 & 3.318 & H1:Rejected \\
\hline Reliability & 0.022 & 0.044 & 0.502 & 0.616 & 0.231 & 4.336 & H2:Rejected \\
\hline Assurance & 0.181 & 0.051 & 3.568 & 0.000 & 0.211 & 4.747 & H3:Accepted \\
\hline Tangibles & 0.222 & 0.046 & 4.880 & 0.000 & 0.249 & 4.015 & H4:Accepted \\
\hline Empathy & 0.117 & 0.050 & 2.349 & 0.019 & 0.198 & 3.053 & H5:Accepted \\
\hline Security & 0.357 & 0.038 & 9.319 & 0.000 & 0.329 & 3.036 & H6:Accepted \\
\hline
\end{tabular}

A Dependent Variable: Customer Satisfaction

$\mathrm{R}=0.894 ; \mathrm{R}^{2}=0.800 ;$ Adj. $\mathrm{R}^{2}=0.797 ;$ S. $\mathrm{E} .=0.352 ;$ F-value $=261.461$,

p-value of F-test $=0.000$.

Sig. at $5 \%$ level

\section{Source: Survey, 2019}

Table 4 shows the F-value and p-value of the regression model were 261.461 and 0.000 , respectively which was significant at a $5 \%$ level of significance. So, the model became linear. $\mathrm{R}$ square of the model was 0.800 , which means the model was estimated 80 percent customer satisfaction variation of service quality dimensions and the remaining $20 \%$ by other constructs. It also demonstrates that all the independent variables except responsiveness and reliability were a significant relationship with customer satisfaction. The main contributor independent variables were security $(\beta=0.357, \mathrm{t}=9.319 .402$, $\mathrm{p}$-value $=.000)$, tangibles $(\beta=$ $0.222, \mathrm{t}=4.880, \mathrm{p}$-value $=.000)$, assurance $(\beta=0.181, \mathrm{t}=3.568, \mathrm{p}$-value $=.000)$, and empathy $(\beta=0.117, \mathrm{t}=2.349$, $\mathrm{p}$-value $=.019)$ respectively. Shrestha and Ale (2020) also found empathy was a significant predictor of customer satisfaction among the service quality dimensions. The SERVQUAL model was proven to be a reliable factor and appropriate instrument for improving the quality of services (Vencataya et al. 2019; Bhatta \& Durgapal, 2016). According to Al-Hashedi (2017), mobile telecom businesses should invest extensively in network improvement and growth to increase network coverage and voice quality, reduce call loss and network congestion during social events, and increase data speeds. Customer satisfaction is an important factor in improving the company's reputation and in a company's long-term existence (Yulisetiarini \& Prahasta, 2019). Delivering high-quality service in a competitive market is the key to gaining a long-term competitive edge in today's world (Agarwal \& Boora, 2018). Independent sample t-test and analysis of variance test were used to examine the moderating effect on customer satisfaction-summary of the test result presented in Table 5. 


\section{Table 5}

Summary of the Results of Hypotheses Testing

\begin{tabular}{|c|c|c|c|c|c|}
\hline \multirow[t]{2}{*}{ Statement } & \multicolumn{2}{|c|}{$\begin{array}{c}\text { Levene's Test } \\
\text { of Equality of } \\
\text { Variances }\end{array}$} & \multicolumn{2}{|c|}{ ANOVA Test } & \multirow[t]{2}{*}{ Remarks } \\
\hline & $\begin{array}{l}\text { F- } \\
\text { value }\end{array}$ & $\begin{array}{c}\mathrm{p}- \\
\text { value }\end{array}$ & $\begin{array}{c}\text { F- } \\
\text { value }\end{array}$ & $\begin{array}{c}\mathrm{p}- \\
\text { value }\end{array}$ & \\
\hline $\begin{array}{l}\text { Ha: Customer satisfaction differs as per } \\
\text { customer's gender }\end{array}$ & 3.054 & 0.081 & & & Rejected \\
\hline $\begin{array}{l}\text { Hb: Customer satisfaction differs as per the } \\
\text { customer's age }\end{array}$ & & & 0.407 & 0.748 & Rejected \\
\hline $\begin{array}{l}\text { Hc: Customer satisfaction differs as per the } \\
\text { customer's occupation }\end{array}$ & & & 0.037 & 0.990 & Rejected \\
\hline $\begin{array}{l}\text { Hd: Customer satisfaction differs as per } \\
\text { customer's education }\end{array}$ & & & 1.382 & 0.248 & Rejected \\
\hline
\end{tabular}

Source: Survey, 2019

Table 5 shows the results of moderating effect of gender, age, occupation, and education on customer satisfaction. An independent-samples t-test was used to test the significant difference in gender regarding customer satisfaction. The male customers satisfaction $($ mean $=3.533$, standard deviation $=0.833$ ) was not significantly different from that of female customers satisfaction (mean $=3.526$, standard deviation $=0.714$ ). Similarly, Levene's test of equality of variance for male and female customers was also not significantly different $(\mathrm{F}$-value $=3.054$, p-value $=0.081)$. With regard to age group, analysis of variance revealed insignificant results $(\mathrm{F}$-value $=0.407, \mathrm{p}$-value $=0.748)$. Analysis of variance of customer's occupation showed insignificant results $(\mathrm{F}$-value $=0.037, \mathrm{p}$-value $=0.990)$. With regard to level of education analysis of variance exhibited insignificant results (F-value = 1.382, p-value $=0.248)$. Dahal (2019) also reported the insignificant result of gender and age group with customer satisfaction.

\section{CONCLUSION}

Nepal Telecommunication has strategies to satisfy its customers. Nepalese telecom consumers are happy with its service. According to the findings, the factors of responsiveness and reliability had little bearing on telecoms' customer satisfaction. Customer dissatisfaction could be the result of delayed and difficult-to-perform precise services. The findings, however, revealed a strong link between assurance, tangibles, empathy, and security. As a result, customer happiness is determined by trust, appearance, close relationships, and information. It also identified security as the major dimension of customer satisfaction, and there is no significant relationship between moderating variables such as gender, age, education, occupation, and customer satisfaction.

Therefore, the SERVQUAL model is critical for predicting total service quality. So it is concluded, even within the telecommunications industry, the dimensionality of SERVQUAL and the relevance of the factors vary depending on the cultural and national environment. As a result, the findings of the study can assist academicians, researchers, practitioners, the telecommunications industry, and governments in improving service quality and boosting customer satisfaction. Since this study was limited to the Kathmandu Valley, more research should be done across the entire country to discover if the outcomes differ. 
Future researchers can broaden the study's scope to obtain more precise results. It aids in the maintenance of a firm's distinct reputation by offering high-quality services and understanding security, tangibles, assurance, and empathy factors that influences customer satisfaction.

\section{ACKNOWLEDGMENTS}

The authors would like to acknowledge "University Grants Commission Sanothimi, Bhaktapur Kathmandu, Nepal for providing Small Research Development and Innovation Grant (SRDIG) to carry out this research work. We also would like to thank Patan Multiple Campus, Patan Dhoka, Lalitpur, Tribhuvan University for continuous encouragement, support, and necessary assistance.

\section{REFERENCES}

Agarwal, J., \& Boora, R. K. (2018). Effects of service quality on customer satisfaction with special reference to Saudi Arabia's mobile telecommunications industry. VSRD International Journal of Business and Management Research, 3(10), 305-314.

Al-Hashedi, S. A. A. (2017). Service quality, customer satisfaction, telecommunication, Yemen. American Journal of Economics, 7(4), 186-193. https://doi.org/10.5923/ j.economics.20170704.04

Arokiasamy, A. R. A., \& Abdullah, D. A. G. (2013). Service quality and customer satisfaction in the cellular telecommunication service provider in Malaysia. Journal of Arts, Science \& Commerce, 4(2), 1-9.

Bhatta, K. R., \& Durgapal, B. P. (2016). Service quality perceptions and customer satisfaction in the Nepalese banking sector. Management Studies, 7(1), 1-7.

Chu, K. H.-L., \& Murrmann, S. K. (2006). Development and validation of the hospitality emotional labor scale. Tourism Management, 27(6), 1181-1191. https://doi.org/ 10.1016/j.tourman.2005.12.011

Cooper, D. R., \& Schindler, P. S. (2014). Business research methods (12 ${ }^{\text {th }}$ ed.). McGrawHill/Irwin.

Dahal, R. K. (2019). Antecedents of customer satisfaction: a case of Nepal telecom gsm network. International Journal of Advanced Research and Publications, 3(8), 136143.

Gautam, D. K. (2016). NTC and Ncell: telecommunication and strategies. South Asian Journal of Business and Management Cases, 5(1), 126-133. https://doi.org/10.1177/ 2277977916634254

Hair, J., Anderson, R., Tatham, R. \& Black, W. (1998). Multivariate data analysis. Prentice Hall, Inc.

Isaac, E. (2018). Test for significance of Pearson's correlation coefficient. International Journal of Innovative Mathematics, Statistics \& Energy Policies, 6(1), 11-23.

Kotler, P. (2011). Philip Kotler's Contributions to Marketing Theory and Practice. In N. K. Malhotra (Ed.), Review of Marketing Research (Vol. 8, pp. 87-120). Emerald Group Publishing Limited. https://doi.org/10.1108/S1548-6435(2011)0000008007

Kotler, P., \& Keller, K. L. (2006). Marketing management $\left(12^{\text {th }}\right.$ ed.). Pearson Prentice Hall. 
Krejcie, R. V., \& Morgan, D. W. (1970). Determining sample size for research activities. Educational and Psychological Measurement, 30(3), 607-610. https://doi.org/ $10.1177 / 001316447003000308$

Marshall, G., \& Jonker, L. (2010). An introduction to descriptive statistics: A review and practical guide. Radiography, 16(4), e1-e7. https://doi.org/10.1016/ j.radi.2010.01.001

Negi, R. (2009). User's perceived service quality of mobile communications: experience from Ethiopia. International Journal of Quality \& Reliability Management, 26(7), 699711. https://doi.org/10.1108/02656710910975769

Neupane, R., \& Devkota, M. (2017). Evaluation of the impacts of service quality dimensions on patient/customer satisfaction: A study of private hospitals in Nepal. International Journal of Social Sciences and Management, 4(3), 165-176. https://doi.org/10.3126/ ijssm.v4i3.17520

Nepal Telecommunication Authority, “Management Information System Report”, 138(186), pp. 1-11, April, 2020.

Nunnally, J. C. (1978). Psychometric theory. New York: McGraw-Hill.

Parasuraman, A., Zeithaml, V. A., \& Berry, L. L. (1985). A Conceptual Model of Service Quality and Its Implications for Future Research. Journal of Marketing, 49(4), 4150. https://doi.org/10.1177/002224298504900403

Rahhal, W. (2015). The effects of service quality dimensions on customer satisfaction: an empirical investigation in Syrian mobile telecommunication services. International Journal of Business and Management Invention, 4(5), 81-89.

Rawlings, J. O., Pantula, S. G., \& Dickey, D. A. (1998). Applied regression analysis: A research tool ( $2^{\text {nd }}$ ed. $)$. Springer.

Ron, A. (2002). Regression analysis and the philosophy of social science: a critical realist view. Journal of Critical Realism, 1(1), 119-142. https://doi.org/10.1558/ jocr.v1i1.119

Santouridis, I., \& Trivellas, P. (2010). Investigating the impact of service quality and customer satisfaction on customer loyalty in mobile telephony in Greece. The TQM Journal, 22(3), 330-343. https://doi.org/10.1108/17542731011035550

Shrestha, P. (2018). Service quality and customer satisfaction: evidence of Nepalese banks. NCC Journal, 3(1), 121-133. https://doi.org/10.3126/nccj.v3i1.20254

Shrestha, R., \& Ale, B. B. (2020). The study of service quality and its relationship on customer satisfaction of Nepal Telecom (NT) in Nepal. International Journal of Advances in Scientific Research and Engineering, 05(12), 112-121. https://doi.org/ 10.31695/IJASRE.2019.33649

Thompson, C. B. (2009). Descriptive Data Analysis. Air Medical Journal, 28(2), 56-59.

Turel, O., \& Serenko, A. (2006). Satisfaction with mobile services in Canada: An empirical investigation. Telecommunications Policy, 30(5-6), 314-331. https://doi.org/ 10.1016/j.telpol.2005.10.003

Vencataya, L., Pudaruth, S., Juwaheer, R. T., Dirpal, G., \& Sumodhee, N. M. Z. (2019). Assessing the impact of service quality dimensions on customer satisfaction in commercial banks of Mauritius. Studies in Business and Economics, 14(1), 259-270. https://doi.org/10.2478/sbe-2019-0020 
Wang, Y., \& Lo, H. (2002). Service quality, customer satisfaction and behavior intentions: Evidence from China's telecommunication industry. Info, 4(6), 50-60. https://doi.org/10.1108/14636690210453406

Yousapronpaiboon, K. (2014). SERVQUAL: measuring higher education service quality in Thailand. Procedia-Social and Behavioral Sciences, 116, 1088-1095. https://doi.org/ 10.1016/j.sbspro.2014.01.350

Yulisetiarini, D., \& Prahasta, Y. A. (2019). The effect of price, service quality, customer value, and brand image on customers satisfaction of Telkomsel Cellular Operators In East Java Indonesia. International Journal Of Scientific \& Technology Research, 8(03), 5-9.

Zeithaml, V. A., Parasuraman, A., \& Berry, L. L. (1985). Problems and strategies in services marketing. Journal of Marketing, 49(2), 33-46. https://doi.org/10.2307/1251563 